\title{
The characteristics of family firms: exploiting information on ownership, kinship, and governance using total population data
}

\author{
Fredrik W. Andersson • Dan Johansson • \\ Johan Karlsson • Magnus Lodefalk • Andreas Poldahl
}

Accepted: 25 September 2017 /Published online: 4 October 2017

(C) The Author(s) 2017. This article is an open access publication

\begin{abstract}
Family firms are often considered characteristically different from non-family firms. However, our understanding of family firms suffers from an inability to identify them in total population data; information is rarely available regarding owners, their kinship, and their involvement in firm governance. We present a method for identifying domiciled family firms using register data; this method offers greater accuracy than previous methods. We apply this method to Swedish data concerning firm ownership, governance, and kinship from 2004 to 2010. We find that the family firm is a significant organizational
\end{abstract}

F. W. Andersson · A. Poldahl

Statistics Sweden, SE 70189 Örebro, Sweden

F. W. Andersson

e-mail: fredrik.andersson@scb.se

A. Poldahl

e-mail: andreas.poldahl@scb.se

D. Johansson $\cdot$ J. Karlsson $(\bowtie) \cdot$ M. Lodefalk

Örebro University School of Business, SE 70182 Örebro, Sweden

e-mail: johan.karlsson@oru.se

D. Johansson

e-mail: dan.johansson@oru.se

M. Lodefalk

e-mail: magnus.lodefalk@oru.se

D. Johansson

HUI Research, SE 10329 Stockholm, Sweden

M. Lodefalk

The Ratio Institute, SE 10364 Stockholm, Sweden form, contributing over one third of all employment and gross domestic product (GDP). Family firms are common in most industries and range in size. Furthermore, we find that, compared to private non-family firms, family firms have fewer total assets, employment, and sales and carry higher solidity, although family firms are more profitable. These differences diminish with firm size. We conclude that the term "family firm" includes a large variety of firms, and we call for increased attention to their heterogeneity.

Keywords Entrepreneur · Family firms · Employment . GDP. Register data

JEL classifications D22 - G38 - H32 - L22 - L25 - L26 . L53

\section{Introduction}

Family business has become a substantial field of research over the past two decades (Bird et al. 2002; Colli 2003; Sharma 2004; Poutziouris et al. 2006; Casillas and Acedo 2007; Benavides-Velasco et al. 2013; GarciaCastro and Aguilera 2014; Xi et al. 2015). Empirical studies indicate that concentration of ownership within a family is common among listed firms and predominant among unlisted firms; additionally, family firms contribute substantially to aggregate employment and income (La Porta et al. 1999; Faccio and Lang 2002; Astrachan and Shanker 2003; Morck et al. 2005; Bertrand and Schoar 2006; Bjuggren et al. 2011). Family businesses have also received increased political attention; they are 
considered the backbone of private industry and a key target for policies aimed at increased employment and economic growth. Consequently, many policies designed to encourage the establishment and growth of family firms have been proposed in both Europe and the USA (European Commission 1994, 2006, 2009). However, some researchers have argued that family businesses are an inefficient way to organize business activities because they put social goals, such as control and nepotism, before economic goals, such as profit and growth. The debate over the efficiency of family ownership is longstanding and remains unsettled (Landes 1949; Chandler 1990; Dyer 2006; Bjuggren 2013; Miller and Le Breton-Miller 2015; Evert et al. 2016).

Given the prevalence of family firms, the theoretical and empirical ambiguity regarding their "successfulness" and the political attention they receive, it is crucial to further investigate their economic contributions and the impact of economic policy on family firms' performance. Both tasks require statistical records of high quality. However, administrative registers generally do not recognize ownership or kinship. Until recently, this fact has made it nearly impossible to use total population data to study family firms, and most family firms have therefore been excluded from research.

A notable exception among previous studies is Bjuggren et al. (2011), who made an initial estimate of the prevalence of domestic family businesses and their contribution to employment and GDP in Sweden. Although the authors' approach was novel, they could only pinpoint kinship between owners for the largest listed firms, and they could not determine whether family members took an active part in the governance of the firm, which is a requirement according to the definition proposed by the European Commission (EC 2009). Our study draws on the work of Bjuggren et al. (2011) and extends it by examining both kinship and governance in all domiciled Swedish firms. We also expand their empirical area of research by studying the characteristics of family firms and by studying family firms including partnerships, limited liability firms, and listed firms across all domestic stock markets. In contrast, Bjuggren et al. (2011) could only examine a portion of all closely held firms and firms listed by NASDAQ OMX Stockholm.

The purpose of our study is threefold. First, we identify all domestic family firms in Sweden from 2004 to 2010 (henceforth, family firms) based on the EC (2009) definition of a family firm. Second, we provide an estimate of the economic contribution of family firms in terms of their share of total employment and GDP. Third, we compare the characteristics (age, being an exporter, being part of an enterprise group, being part of a multinational enterprise, employment, labor productivity, physical capital intensity, return on assets, sales, skill intensity, solidity, and total assets) of family firms and private, domestically held non-family firms (henceforth, private non-family firms).

To identify family firms, we first use information on legal forms and ownership categories to find potential family firms. ${ }^{1}$ Next, we utilize complete statistical records from Statistics Sweden to trace kinship among all Swedish residents and, from that, kinship among all registered owners and top managers (chief executive officers and board members) across all domestic firms, including both listed and non-listed firms. This allows us to identify all Swedish families who reside in Sweden and classify all listed and non-listed firms as family firms or non-family firms according to the EC (2009) definition.

We find that family firms are the dominant organizational form: they range in size from small producers to large multinational firms, and they are active in all industries when not crowded out by government actors. The Swedish welfare state constitutes approximately one third of the economy and operates mainly within the domains of health care, education, and public administration. These markets were deregulated in the 1990s, but private entrepreneurship is still hampered by remaining regulations and competition from government actors (Henrekson and Johansson 2009). Consequently, we find relatively few family firms in these industries.

We estimate that family firms generate over one third of GDP and total employment, of which nearly all is generated by limited liability firms, while partnerships and sole proprietorships are of less economic significance. The typical family firm is less reliant on formal knowledge, is less involved in exports, and has lower labor productivity than the typical private non-family firm. In addition, family firms also have lower employment, sales, and total assets, even among firms of similar size. Family firms have higher solidity, yet we find them to be more profitable. Lastly, we find that the differences between family firms and private non-family firms diminish with firm size.

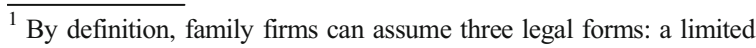
liability firm, partnership, or sole proprietorship. Ownership category is a statistical term that identifies whether a firm's ownership is foreign, governmental, or private. Only privately owned firms were counted as family firms.
} 
This paper is organized as follows: the next section reviews approaches to defining and identifying family firms. Section 3 describes our data and outlines the methods we used to identify family firms. Section 4 reports the number and economic contribution of family firms as well as their industries and size distribution. Section 5 examines the characteristics of family firms using descriptive statistics and econometric estimations. Section 6 provides a concluding discussion.

\section{Conceptual framework: defining family firms}

What constitutes a family firm? This question has been considered by numerous authors, and the most common ways of defining family firms are to focus on either firm ownership or firm governance, as exemplified by Davis and Taguiri (1996), Donckels and Frohlich (1991), La Porta et al. (1999), Faccio and Lang (2002), and Anderson and Reeb (2003). Most empirical research on family firms has manually identified family firms based on listed firms or firm samples. Family ownership has been identified from sources such as the business press, business reports, interviews, and questionnaires. An exception is Bennedsen et al. (2007), who employed register-based data from Denmark to identify kinship bonds between incoming and departing CEOs in publicly held limited liability firms. The study did not, however, examine firm ownership.

Another exception is Bjuggren et al. (2011), who studied family ownership across firms using register data and knowledge of Swedish corporate law and the Swedish tax system. Bjuggren et al. (2011) noted that the 1991 tax reform in Sweden introduced special rules for closely held firms and that the tax authority examined family relationships to ensure compliance with the rules. The authors used this data alongside information on legal forms, categorization of ownership, and knowledge of the owners of the largest listed Swedish firms to estimate the prevalence of domestic family business and its contribution to employment and GDP. They could not, however, identify kinship between owners other than for large listed firms. They also could not determine whether family members took an active part in the governance of a firm (except for large listed firms), which is a requirement according to the EC (2009) definition.
We apply the EC (2009) definition, which states that a firm of any size should be classified as a family firm if it meets the following criteria:

i. The majority of decision-making rights are in the possession of the natural person(s) who established the firm, or in the possession of the natural person(s) who has/have acquired the share capital of the firm, or in the possession of their spouses, parents, child, or children's direct heirs. ${ }^{2}$

ii. The majority of decision-making rights are indirect or direct.

iii. At least one representative of the family or kin is formally involved in the governance of the firm.

iv. Listed companies meet the definition of family enterprise if the person(s) who established or acquired the firm (share capital) or their families or descendants possess $25 \%$ of the decision-making rights mandated by their share capital.

In other words, the EC (2009) definition states that a family firm is one in which an individual or family controls a majority of the decision-making rights (or, in the case of listed firms, a quarter of the decisionmaking rights) and where at least one family member is formally involved in the firm's governance.

The EC (2009) definition was chosen for two reasons: First, the definition is based on an extensive meta-analysis of family businesses in a European context, suggesting that it is the most suitable definition for the purposes of our study. Second, recognized organizations, such as the European Union, and multinational family business networks, including the European Group of Owner Managed and Family Enterprises, the Family Business Network (FBN) International, and the Family Firm Institute, have used the definition. This level of support indicates that the definition will continue to be used in the future. In addition, several studies have used the definition, including Bjuggren et al. (2011), whose work we draw upon and with which we compare our results. ${ }^{3}$

\footnotetext{
$\overline{2}$ Decision-making rights are used synonymously with voting rights. For approximately $10 \%$ of all closely held firms, we lack ownership information. For these firms, we instead use information on executive board members to identify family firms. In this case, we depart from the EC (2009) definition. Additional analysis of closely held firms with ownership information indicates that this is a reasonable approximation.

${ }^{3}$ Other studies include Grundström et al. (2012), Bjuggren et al. (2013), Backman and Palmberg (2015), and Bornhäll et al. (2016).
} 


\section{Data and identification of family firms}

The EC (2009) definition encompasses a vast number of organizations. There is relatively little information available for most of these organizations; therefore, we turn to administrative registers to identify family firms.

Our study is based exclusively on administratively compiled registers from Statistics Sweden that cover all firms, residents, and employees in Sweden for the period from 2004 to 2010. The bulk of our information comes from the Swedish Register-Based Labor Market Statistics. We complement this source with data from the Swedish Ownership Register, the Swedish Financial Supervisory Authority's Central Registers of Investments and Investor Alerts, the Swedish Companies Registration Office's Executive Board Register, the Swedish Tax Agency's statistics on earnings and deductions, the Swedish Structural Business Statistics, and the Swedish Multi-generation Register. All the sources listed above include total population data. ${ }^{4}$

These data include a vast amount of detail: The Swedish Register-Based Labor Market Statistics contains matched employer-employee data on all active firms and all individuals who are part of the Swedish labor market, including non-residents (foreign citizens working in Sweden). This information is complemented by data on all physical and legal persons who own stocks in listed firms in Sweden from the Swedish Ownership Register. ${ }^{5}$ Moreover, we include information on all Swedish citizens who control at least $10 \%$ of a listed firm, and any legal person that holds equity in a listed firm from the Swedish Financial Supervisory Authority's Central Register of Investments and Investor Alerts. The information in both the Swedish Ownership Register and the Swedish Financial Supervisory Authority's Central Register of Investments and Investor Alerts includes all listed firms in Sweden and is presented by the type and number of shares held by each individual, the holding's size relative to the total capital stock, and

\footnotetext{
${ }^{4}$ Swedish translations of all included data sources can be found in Appendix A.

5 The Swedish Ownership Register is supplied to Statistics Sweden by Euroclear Sweden AB, which is the authorized central depositing agency for financial securities in Sweden. Euroclear Sweden receives notifications of all purchases and sales of stocks in listed firms in Sweden under the Law of Accounting of Financial Instruments (SFS1998:1479). SFS refers to the Swedish Code of Statutes.
}

the number of votes that the holding grants in the firm. The data are detailed enough to discern both direct and indirect ownership; thus, all equity held by the subsidiaries of a parent company can be attributed to the owners of the parent company within an enterprise group. This approach has been used to account for pyramid ownership, which is common among larger family firms (Holmén and Högfeldt 2009; La Porta et al. 1999).

We also include information on all executive board members in limited liability firms in Sweden during a given year from the Swedish Companies Registration Office's Executive Board Register. The information contained in the Executive Board Register is complete: Swedish limited liability firms are required by law to register an executive board and provide details regarding the board's composition. Moreover, we include information on all taxable income in Sweden during a given year from the Swedish Tax Agency's statistics on earnings and deductions. The information is complete for all firms, including for both owners and employees.

Finally, we retrieve information on the parents of all residents (both biological and adoptive) from the Swedish Multi-generation Register. The Multi-generation Register includes all individuals born in 1932 or later who were registered as Swedish citizens at some point since 1968. Once all family firms were identified, we extend our analysis by including financial information from the Swedish Structural Business Statistics. This methodology allows us to fully characterize Swedish family firms and non-family firms.

\subsection{Identifying potential family firms}

By definition, family firms can only take the form of limited liability firms, partnerships, and sole proprietorships. Sole proprietorships are firms that are registered to their founders, who exhibit complete control over the firm, and who are fully responsible for the firm's activities. Sole proprietorships are therefore family firms by default and include slightly more than 200,000 firms that employ nearly 300,000 people. $^{6}$

We exclude government and foreign-owned firms from consideration among limited liability firms and

\footnotetext{
${ }^{6}$ The definition of sole proprietors as family firms is also used by the EC (2009) definition and an earlier report by Mandl (2008).
} 
partnerships. In the first case, governmentally owned firms cannot be family firms; in the second, we lack information regarding foreign owners, including both foreign citizens and Swedish citizens residing abroad. ${ }^{7}$

The next step is to distinguish family firms from nonfamily firms among private, domiciled limited liability firms and partnerships. In total, they constitute approximately half a million firms that employ approximately 1.2 million people. First, however, it is necessary to identify kinship and define the term "family."

\subsection{Identifying kinship and defining the family}

One fundamental question of the study remains unanswered: "What is a family?" The question is non-trivial in the context of family business research, and the approach chosen by a study will likely influence its results (Handler 1989; Astrachan and Shanker 1996; Kraus et al. 2011). To define the term "family" in a value-neutral way, we have chosen to include all information on registered kinship available within Swedish administrative registers.

We use the Swedish Population Register and the Swedish Multi-generation Register to identify all parents, siblings, aunts, uncles, and cousins of all Swedish citizens in a given year. These data allow us to identify firms in which up to two generations are active. We note, however, that some family firms may include more distant relatives.

Therefore, as a second step, we include all known relatives on the father's side of the family, starting with the family of each individual's grandparents and working our way backwards. This process was repeated for all generations until no elder relative can be found. All

\footnotetext{
${ }^{7}$ There are no estimates of employment in firms owned by Swedes that have moved abroad, but there is a general understanding that this group probably accounts for a non-negligible share of Swedish employment. There was an exodus of successful Swedish entrepreneurs during the 1960s, 1970s, and 1980s because of a highly unfavorable tax system, which in many cases had confiscatory effects. To develop their firms and maintain ownership within the family, many entrepreneurs moved from Sweden to countries such as Belgium, the Netherlands, Switzerland, or the UK. The best-known examples are IKEA and Tetra Pak, controlled by the Kamprad and Rausing families, respectively (Henrekson and Johansson 1999; Henrekson 2005; Henrekson and Stenkula 2015; Johansson et al. 2016). Tax reforms have significantly improved the conditions for entrepreneurs since the early 1990s. For instance, capital income tax rates have been cut and wealth and inheritance taxes have been abolished. These policies have considerably reduced incentives for a firm to move outside Sweden to ease its tax burden (Henrekson 2017).
}

individuals who share kinship through a common relative, either by blood or marriage, are included in the term "family." At most, kinship across up to five generations can be identified using this method, although in practice $98 \%$ of families include one to three generations. ${ }^{8} \mathrm{We}$ chose identify families by the father, as men are more likely to control the family firm; for example, $76 \%$ of all top managers in Sweden are males. This choice does not affect our results because our method includes all spouses, siblings, and children for all individuals.

\subsection{Identifying listed family firms}

To identify listed family firms, we use information on holdings in all listed firms where our information is detailed enough to discern the owner of each individual equity. ${ }^{9}$ Ownership is then measured as each individual's total number of voting rights. We then attribute all ownership by Swedish residents to the families previously identified, which includes both direct ownership by Swedish residents and indirect ownership through Swedish firms and foundations. ${ }^{10}$ Next, we control for whether the owning family has at least one family member present on the firm's executive board or holds the position of managing director. Finally, we apply the EC (2009) definition and classify all listed firms in which a family controls at least $25 \%$ of the decision-making rights as family firms. The process identified approximately 108 family firms out of 415 listed firms (approximately one fourth of listed firms). These firms employ slightly more than 78,000 people, corresponding to approximately one fourth of employment in listed firms.

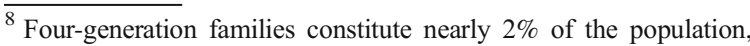
while five-generation families constitute $0.01 \%$. Additional analysis shows that nearly all family firms are controlled across 1 to 2 generations.

${ }^{9}$ This includes both domestic and foreign owners, who can be both physical and legal persons. However, we do not have any additional information on foreign owners apart from their names and shareholdings.

${ }^{10}$ This indicates that all the equity held by a parent company's subsidiaries is attributed to the owners of the parent company within an enterprise group. Pyramidal ownership is therefore taken into account.
} 
3.4 Identifying family firms among non-listed limited liability firms

Non-listed limited liability firms can be closely held or widely held. In closely held firms, at least $50 \%$ of a firm is owned by four or fewer owners, and an individual and his or her closest of kin are regarded as one owner. ${ }^{11}$ All nonlisted firms that do not fulfill this condition are therefore classified as widely held. For non-listed limited liability firms, we do not have information on each owner's voting rights. However, owners of closely held firms must report their capital income tax individually using a special form; we use these forms to identify these owners. Thus, we can identify all known owners of closely held firms in Sweden. We then assume that the holdings of all closely held firms are equally distributed among their owners and define them as family firms if at least half of the involved owners are related.

Closely held firms that have not filed for capital income under these special tax rules typically are not identified as closely held in registers because the tax authority has not reviewed their ownership structure. This suggests that there are family firms that are classified as "widely held" in registers that should actually be considered closely held. Closely held firms without ownership information are identified using information from their executive board structure; firms are classified as family firms if at least half the executive board is related by marriage or blood.

This method identified approximately 137,000 family firms through ownership information and an additional 19,000 family firms via executive board structure, yielding a total of slightly less than 156,000 non-listed limited liability family firms (approximately $90 \%$ of all domestically and privately held limited liability firms). These firms employ nearly 1.1 million people (approximately half of employment within all private and domiciled limited liability firms).

\subsection{Identifying family firms among joint and limited partnerships}

By definition, joint and limited partnerships do not have any stocks. Therefore, we classify them as family

\footnotetext{
${ }^{11}$ Closest of kin is defined as those individuals who are related across a maximum of three generations, including an individual's grandparents, parents, siblings, children, nieces, and nephews, and the spouses of all of the above.
}

controlled if at least half of the involved partners are related. ${ }^{12}$ The process identified slightly less than 27,000 such family firms (approximately $90 \%$ of all joint and limited partnerships), which employ approximately 58,000 people (approximately four fifths of employment in partnerships).

\subsection{The population of family firms}

In total, we identified nearly 410,000 family firms (Table 1). Compared to the total number of employer firms, we find that family firms are by far the most common organizational form in Sweden, accounting for approximately $90 \%$ of all employer firms and organizations. Approximately half of the family firms are sole proprietorships, whereas limited liability firms constitute approximately $40 \%$, and partnerships represent the rest.

\section{The economic contribution of family firms}

In this section, we examine the contribution of family firms to total employment and GDP. We also examine these firms' numbers as well as their industries and size distributions.

First, we compare family firms and other organizations across the entire population. The analysis is then delimited to the legal forms in which family firms can be active: limited liability firms, partnerships, and sole proprietorships. Ownership of these firms is then compared across size classes. All the comparisons involve employer firms (firms that employ at least one person), apart from calculations of GDP, which include all firms. All analyses are conducted for the most recent year of data, 2010, unless otherwise specified.

\subsection{The economic contribution of family firms}

Family firms contribute approximately one third of all employment in Sweden (see Table 2). Furthermore, we find that family firms contribute an equal share of

\footnotetext{
$\overline{12}$ In the case that a partnership is a subsidiary, it is classified according to the ownership of the parent company.
} 
Table 1 The number and share (\%) of family firms and other ownership categories across legal forms in 2010

\begin{tabular}{|c|c|c|c|c|c|c|c|c|c|c|}
\hline \multirow{2}{*}{$\begin{array}{l}\text { Ownership category } \\
\text { Legal form }\end{array}$} & \multicolumn{2}{|l|}{ Family } & \multicolumn{2}{|c|}{ Private, non-family } & \multicolumn{2}{|c|}{ Foreign } & \multicolumn{2}{|c|}{ Government } & \multicolumn{2}{|l|}{ Total } \\
\hline & & $\%$ & & $\%$ & & $\%$ & & $\%$ & & $\%$ \\
\hline Central and local government & - & - & - & - & - & - & 266 & 100 & 266 & 0 \\
\hline Listed limited liability firms & 108 & 26 & 285 & 69 & 22 & 5 & 0 & 0 & 415 & 0 \\
\hline Non-listed limited liability firms & 155,736 & 89 & 11,057 & 6 & 7365 & 4 & 0 & 0 & 174,158 & 41 \\
\hline Partnerships & 26,671 & 93 & 1985 & 7 & 48 & 0 & 2 & 0 & 28,706 & 6 \\
\hline Sole proprietorships & 218,486 & 100 & - & - & 45 & 0 & - & - & 218,531 & 48 \\
\hline Other legal forms & - & 42 & 38,654 & 51 & 2122 & 5 & 784 & 2 & 41,560 & 5 \\
\hline Total & 418,453 & 90 & 34,529 & 7 & 9602 & 2 & 1052 & 0 & 463,636 & 100 \\
\hline
\end{tabular}

Statistics Sweden reports three ownership categories for firms and organizations: foreign, governmental, or private ownership. We identified family firms within the "privately owned" category, which we divided into the subcategories "family" and "private, non-family." Only employer firms, i.e., firms that employ at least one person, are included. Legal forms are assigned according to the ownership and legal form of the parent company. This means that all government-owned limited liability firms are attributed to central and local governments

Source: registers presented in Section 3

Swedish GDP. ${ }^{13}$ In other words, our results show that family firms are not only the largest employers but also the single greatest source of value added in Sweden, indicating that family business is not the exception, as is often depicted, but rather the rule of economic activity. These numbers are particularly interesting considering that both businesses and wealth were highly taxed in Sweden during the 1960s, 1970s, and 1980s, which resulted in a considerable number of family firms migrating, being sold, or perishing (Henrekson and Johansson 1999: Henrekson 2005; Henrekson and Johansson 2009).

Our estimates are higher than those of Bjuggren et al. (2011), who reported that family firm employment and GDP accounted for one fourth and one fifth of these totals, respectively. This discrepancy arises because, unlike Bjuggren et al. (2011), we identify family control using kinship information and information across all domestic stock markets, partnerships, and limited liability firms. Our results are therefore both more inclusive and more precise than those of Bjuggren et al. (2011).

Family firms generate all employment among sole proprietorships, by definition. They also account for

\footnotetext{
$\overline{{ }^{13} \text { Family firms' }}$ share of GDP is calculated using their share of private sector value added and comparing that share to official estimates of private sector GDP. The contributions to total employment and GDP are stable over the studied time period (results not shown here). For additional details on the method used to estimate family firm GDP, see our working paper version, Andersson et al. (2017).
}

most employment among partnerships and approximately half of employment among limited liability firms.

Table 3 shows the distribution of family firms across industries, which are presented in accordance with the Statistical Classification of Economic Activities in the European Community (NACE rev 1.1, first level). We find that family firms represent a significant share of all employment in the second, third, and fourth largest industries in Sweden: manufacturing (D), real estate, renting and business activities (K), and wholesale and retail trade $(\mathrm{G})$, with 41,43 , and $60 \%$, respectively. Together, these industries account for over $40 \%$ of all employment.

Conversely, family firms are relatively uncommon in health and social work $(\mathrm{N})$, which is also the single largest industry in Sweden. This industry accounts for approximately $20 \%$ of all employment, of which family firm employment represents approximately $6 \%$. Similar patterns can be observed in other industries that have traditionally been dominated by government actors, such as public administration and defense (L) and education (M). These markets were opened up for entrepreneurs in the early 1990s. The lack of family firms in these industries is likely due to remaining regulations that restrict entrepreneurship and to competition from government actors (Henrekson and Johansson 2009).

Another aspect of the composition of family firms is their distribution by size, as presented in Table 4 . 
Table 2 The number and share (\%) of employment in family firms and other ownership categories across legal forms in 2010

\begin{tabular}{|c|c|c|c|c|c|c|c|c|c|c|}
\hline \multirow{2}{*}{$\begin{array}{l}\text { Ownership category } \\
\text { Legal form }\end{array}$} & \multicolumn{2}{|l|}{ Family } & \multicolumn{2}{|c|}{ Private, non-family } & \multicolumn{2}{|l|}{ Foreign } & \multicolumn{2}{|c|}{ Government } & \multicolumn{2}{|l|}{ Total } \\
\hline & & $\%$ & & $\%$ & & $\%$ & & $\%$ & & $\%$ \\
\hline Central and local government & - & - & - & - & - & - & $1,466,742$ & 100 & $1,466,742$ & 33 \\
\hline Listed limited liability firms & 78,325 & 25 & 225,099 & 71 & 14,671 & 5 & 0 & 0 & 318,095 & 7 \\
\hline Non-listed limited liability firms & $1,109,870$ & 49 & 501,347 & 22 & 642,862 & 29 & 0 & 0 & $2,254,079$ & 51 \\
\hline Partnerships & 58,301 & 77 & 12,515 & 17 & 4859 & 6 & 40 & 0 & 75,715 & 2 \\
\hline Sole proprietorships & 268,568 & 100 & - & - & 87 & - & - & - & 268,655 & 6 \\
\hline Other legal forms & 17,434 & 89 & 2069 & 11 & 0 & 0 & 0 & 0 & 19,503 & 0 \\
\hline Total & $1,532,498$ & 35 & 741,030 & 17 & 662,479 & 15 & $1,466,782$ & 33 & $4,402,789$ & 100 \\
\hline
\end{tabular}

Statistics Sweden reports three ownership categories for firms and organizations: foreign, governmental, or private ownership. We identified family firms within the "privately owned" category, which we divided into the subcategories "family" and "private, non-family." Employment is assigned according to the ownership and legal form of the parent company. This means that all employment in government-owned limited liability firms is attributed to central and local governments

Source: registers presented in Section 3

Family firms account for nearly all employment among micro-firms (approximately 90\%). Among limited liability firms, however, family firms account for approximately half of employment (not shown in the table). The contribution of family firms diminishes with firm size, although they contribute the lion's share of employment among small firms. These results are expected: small firms are thought to be characterized by a higher concentration of family ownership than larger firms. Ownership is likely to be diffused as firms grow (Demsetz and Lehn 1985; Himmelberg et al. 1999). Foreign owners can also be expected to have stronger preferences for investing in larger firms due to transaction costs (Bjuggren et al. 2011). Additionally, family firms are often crowded out by the government, which employs people in large firms (see Table 4). Nevertheless, family firms contribute approximately $1 / 12$ of all large firm employment.

\section{The characteristics of family firms}

Having described the economic significance of family firms, we now compare the characteristics of family versus non-family firms. First, we present descriptive statistics on family firms and non-family firms across a selection of firm characteristics that have been identified using survey articles (see below). Next, we examine whether these characteristics differ between family firms and private non-family firms by comparing mean values using $t$ tests. We complement the $t$ tests with a rudimentary regression model that investigates the correlations between family ownership and firm characteristics while controlling for potentially confounding factors that are exogenous to our discussion, such as industry- and sizespecific heterogeneity. We emphasize that we interpret the econometric results as correlations and that we do not intend to identify causal relationships.

To determine which aspects of family firms and private non-family firms to characterize, we examined literature reviews covering recent trends in family business research (Sharma et al. 1997; Sharma 2004; Gedajlovic et al. 2012; Hiebl 2012; Kontinen and Ojala 2010; Mazzi 2011; Yu et al. 2012; Xi et al. 2015). Based on these reviews, we identify six commonly discussed aspects within family business research that have been used to distinguish family from non-family firms: financial performance, financial composition, risk preference, firm age, firm size, and internationalization.

Financial performance is commonly presented in terms of return on assets (earnings before interest and taxes, EBIT; and earnings before interest, tax, depreciation, and amortization, EBITDA). Therefore, we therefore include these measures in our analysis. ${ }^{14}$ In line with other studies, solidity (Solidity) is used as a measure of financial composition and risk preference.

We also include firm age based on each firm's year of founding (Age). Firm size is represented by three

\footnotetext{
${ }^{14}$ Tobin's $Q$ is also commonly used in the literature. However, there is no market value on non-listed firms, which is necessary to calculate Tobin's $Q$. Therefore, we could not include this measure in our analysis.
} 
Table 3 Employment in family firms across industries in 2010

\begin{tabular}{|c|c|c|c|c|c|c|c|c|c|c|c|}
\hline \multirow[b]{2}{*}{ Code } & \multirow{2}{*}{$\begin{array}{l}\text { Ownership category } \\
\text { Industry }\end{array}$} & \multicolumn{2}{|l|}{ Family } & \multicolumn{2}{|c|}{$\begin{array}{l}\text { Private, } \\
\text { non-family }\end{array}$} & \multicolumn{2}{|l|}{ Foreign } & \multicolumn{2}{|c|}{ Government } & \multicolumn{2}{|l|}{ Total } \\
\hline & & & $\%$ & & $\%$ & & $\%$ & & $\%$ & & $\%$ \\
\hline A & Agriculture, hunting, and forestry & 69,262 & 88 & 7178 & 9 & 1002 & 1 & 1621 & 2 & 79,063 & 2 \\
\hline B & Fishing & 1299 & 94 & 36 & 3 & 54 & 4 & - & - & 1389 & 0.03 \\
\hline $\mathrm{C}$ & Mining and quarrying & 1970 & 21 & 2661 & 28 & 1086 & 12 & 3626 & 39 & 9343 & 0.2 \\
\hline $\mathrm{D}$ & Manufacturing & 177,597 & 41 & 39,359 & 9 & 213,892 & 49 & 1748 & 0.4 & 432,596 & 10 \\
\hline $\mathrm{E}$ & Electricity, gas, and water supply & 5719 & 21 & 1926 & 7 & 7216 & 27 & 12,295 & 45 & 27,156 & 1 \\
\hline $\mathrm{F}$ & Construction & 192,973 & 78 & 21,726 & 9 & 25,482 & 10 & 6147 & 2 & 246,328 & 6 \\
\hline G & $\begin{array}{l}\text { Wholesale and retail trade; repair of motor } \\
\text { vehicles, motorcycles, and personal and } \\
\text { household goods }\end{array}$ & 277,206 & 60 & 57,145 & 12 & 116,631 & 25 & 14,887 & 3 & 465,869 & 11 \\
\hline $\mathrm{H}$ & Hotels and restaurants & 93,509 & 77 & 9549 & 8 & 18,816 & 15 & 282 & 0.2 & 122,156 & 3 \\
\hline I & Transport, storage, and communication & 140,470 & 43 & 61,140 & 19 & 105,713 & 33 & 15,661 & 5 & 322,984 & 7 \\
\hline $\mathrm{J}$ & Financial intermediation & 30,254 & 25 & 69,103 & 58 & 16,409 & 14 & 4206 & 4 & 119,972 & 3 \\
\hline K & Real estate, renting, and business activities & 357,425 & 43 & 289,757 & 35 & 107,769 & 13 & 81,015 & 10 & 835,966 & 19 \\
\hline $\mathrm{L}$ & $\begin{array}{l}\text { Public administration and defense; } \\
\text { compulsory social security }\end{array}$ & 132 & 0.1 & 1741 & 1 & 47 & 0.03 & 151,926 & 99 & 153,846 & 3 \\
\hline M & Education & 29,106 & 7 & 42,933 & 10 & 2557 & 1 & 360,820 & 83 & 435,416 & 10 \\
\hline $\mathrm{N}$ & Health and social work & 53,897 & 6 & 42,766 & 5 & 37,773 & 4 & 803,820 & 86 & 938,256 & 21 \\
\hline $\mathrm{O}$ & $\begin{array}{l}\text { Other community, social, and personal service } \\
\text { activities }\end{array}$ & 63,153 & 38 & 90,630 & 54 & 5001 & 3 & 8674 & 5 & 167,458 & 4 \\
\hline $\mathrm{P}$ & Activities of households & 2 & 67 & - & - & 1 & 33 & - & - & 3 & 0.0001 \\
\hline Q & Extra-territorial organizations and bodies & - & - & - & - & 699 & 100 & - & - & 699 & 0.02 \\
\hline \multirow[t]{2}{*}{-} & Unknown industry & 38,524 & 87 & 3380 & 8 & 2331 & 5 & 54 & 0.1 & 44,289 & 1 \\
\hline & Total: & $1,532,498$ & 35 & 741,030 & 17 & 662,479 & 15 & $1,466,782$ & 33 & $4,402,789$ & 100 \\
\hline
\end{tabular}

Statistics Sweden reports three ownership categories for firms and organization: foreign, governmental, or private ownership. We identified family firms within the "privately owned" category, which we divided into the subcategories "family" and "private, non-family" in this table. Industries are reported in accordance with NACE rev. 1.1

Source: registers presented in Section 3

commonly used variables: number of employees (Employment), sales (Sales), and total assets (Total assets). The internationalization of firms is commonly measured in the literature using export propensity (Being an exporter) and whether a firm is part of a multinational enterprise (Being part of an MNE).

Table 4 The number and size distribution (\%) of employment in family and private non-family firms in 2010

\begin{tabular}{|c|c|c|c|c|c|c|c|c|c|c|}
\hline Ownership category & Family & & Private, non-family & & Foreign & & Government & & Total & \\
\hline Size & & $\%$ & & $\%$ & & $\%$ & & $\%$ & & $\%$ \\
\hline Micro-firms & 702,463 & 88 & 16,640 & 2 & 745 & 0 & 75,818 & 10 & 795,666 & 18 \\
\hline Small firms & 416,167 & 67 & 62,717 & 10 & 5448 & 1 & 135,590 & 22 & 619,922 & 14 \\
\hline Medium-sized firms & 210,440 & 41 & 144,736 & 28 & 20,763 & 4 & 134,431 & 26 & 510,370 & 12 \\
\hline Large firms & 192,326 & 8 & 438,386 & 18 & $1,439,826$ & 58 & 406,293 & 16 & $2,476,831$ & 56 \\
\hline Total & $1,521,396$ & 35 & 662,479 & 15 & $1,466,782$ & 33 & 752,132 & 17 & $4,402,789$ & 100 \\
\hline
\end{tabular}

Firm sizes are defined by the number of employees: micro (<9), small (10-49), medium (50-249), and large ( $\geq 250)$. We identified family firms within the "privately owned" category, which we divided into the subcategories "family" and "private, non-family"

Source: registers presented in Section 3 
Finally, as economists, we are also interested in three measures that are common in economics, though less so in the family business literature: human capital intensity, physical capital intensity, and labor productivity. We also include these measures in our analysis. Human capital intensity is measured in terms of skill intensity (Skill intensity), which is the share of employees with tertiary education, while physical capital intensity is measured as physical capital per employee (Physical capital employee). Labor productivity is measured in terms of value added per employee. We also use the question of whether a firm is part of an enterprise group (Being part of an enterprise group) to capture another dimension of ownership relations that has been a topic of research, i.e., if a firm is independent or part of a larger organization. In total, we included 13 variables in the analysis.

Our analysis encompasses family firms and domiciled, private, non-family firms only. This is because foreign firms include both family and non-family firms, and we cannot distinguish between them. Government firms are also excluded because government and private organizations differ in numerous ways; for instance, in terms of the owners' objectives and because the government has "unlimited" access to funds through the right to taxation and the right to print money.

We note that accounting principles and regulations differ across legal forms, and the most important differences concern equity restrictions and economic liability. Thus, firms with various legal forms are established and governed according to their owners' differing ambitions and purposes, which renders them difficult to compare. We therefore restrict our analysis to limited liability firms (both listed and non-listed) because they are the most economically significant group.

Table 6 shows that the average and median values for family firms are significantly smaller than for private non-family firms in terms of employment, sales, and total assets. This result is consistent with the findings of Backman and Palmberg (2015) and Dow and McGuire (2016). The average and median age of family firms is also greater. Furthermore, we find that family firms are less likely to take part in enterprise groups and to employ skilled personnel. They employ less physical capital on average, although more on the median. In terms of performance, family firms have a higher average and median return on assets in terms of EBITDA but lower in terms of EBIT, although the differences in mean are not significant. In addition, they have approximately the same solidity as non-family firms and lower labor productivity than the average and median private non-family firms. Finally, family firms are significantly less involved in multinational enterprises and exports than their private non-family counterparts.

The above comparisons do not examine the characteristics of family firms while controlling for other factors such as industry and size. Therefore, in Tables 7 and 8, we employ ordinary least squares (OLS), quantile, and probit regression models to control for industry, year, and, when applicable, firm size. We use these measures to illustrate the general characteristics of family firms and non-family firms among limited liability firms.

\subsection{Econometric specification and results}

We regress the 13 firm characteristics discussed above on a family firm dummy and three firm-level features: firm size, industry, and year. This yields a descriptive characterization of the population of family firms while controlling for rudimentary confounding factors. Firm characteristics may differ across firm size; therefore, we control for the number of employees per firm (Firm size). Due to collinearity, this variable is excluded when we analyze size-related characteristics (Employment, Sales, and Total assets). The characteristics of firms are also likely to differ across industries. Therefore, we also control for the industry to which each firm belongs (Industry). Industry is controlled for at the two- and three-digit levels according to the NACE rev 1.1. Finally, we control for the year in which each firm was observed (Year). The model can be summarized as follows:

$$
\begin{aligned}
Y_{\mathrm{it}}= & \alpha_{i}+D_{1} \text { Family }_{\mathrm{it}}+\text { OFirm }_{\text {size }} \mathrm{it}_{\mathrm{it}} \\
& ++ \text { Industry }_{\mathrm{it}}+\text { Year }_{t}+\epsilon_{\mathrm{it}}
\end{aligned}
$$

where $Y_{\text {it }}$ represents the 13 firm characteristics presented above, and $\epsilon_{\mathrm{it}}$ is the error term. ${ }^{15}$ The response variables differ in terms of their distribution, and we therefore divide them into categories: continuous variables (Age, EBIT, EBITDA, Employment, Labor productivity, Physical capital intensity, Sales, Skill intensity, Solidity, and Total assets) and binary variables (Being an exporter, Being a member of an enterprise group, and Being part of an MNE).

Three of the continuous variables (Age, Employment, and Skill intensity) are analyzed using a standard OLS specification. All binary variables are analyzed

\footnotetext{
${ }^{15}$ For brevity, industry indices are suppressed in Equation 1.
} 


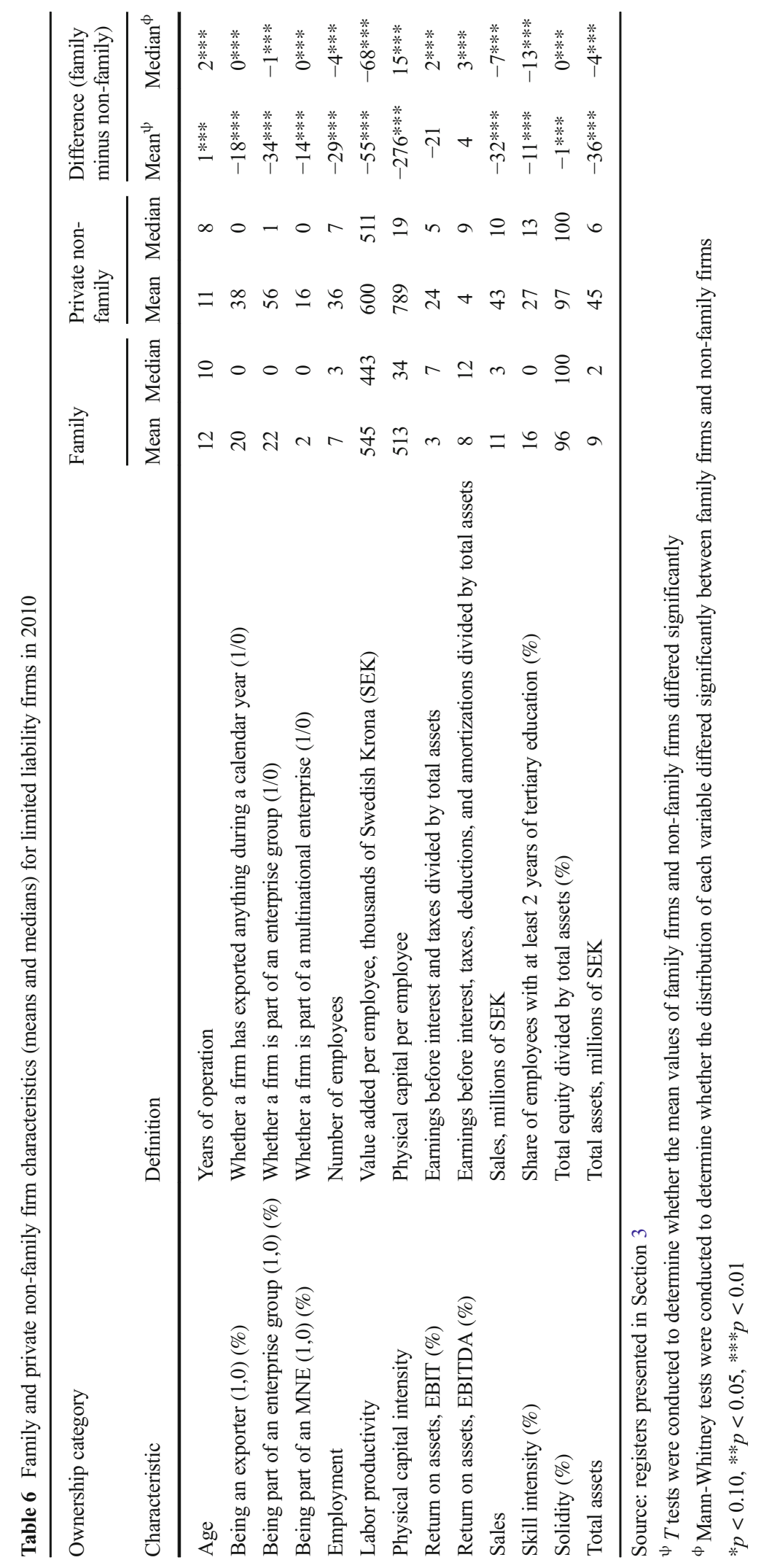


Table 7 Comparison of the characteristics of limited liability family firms and private limited liability non-family firms (pooled OLS/ median/logistic estimates) from 2004 to 2010

\begin{tabular}{|c|c|c|c|}
\hline Dependent variable & Explanatory variable, family firm dummy & Adjusted $R^{2}$ & Observations \\
\hline Age & $\begin{array}{l}2.292 * * * \\
(0.064)\end{array}$ & 0.10 & $1,166,579$ \\
\hline Employment (log) & $\begin{array}{l}-1.080 * * * \\
(0.009)\end{array}$ & 0.21 & $1,166,579$ \\
\hline Sales $(\log )$ & $\begin{array}{l}-1.191 * * * \\
(0.015)\end{array}$ & 0.14 & $1,079,832$ \\
\hline Total assets $(\log )$ & $\begin{array}{l}-1.204 * * * \\
(0.011)\end{array}$ & 0.22 & $1,072,832$ \\
\hline Return on assets, EBITDA (\%) & $\begin{array}{l}3.538 * * * \\
(0.061)\end{array}$ & 0.02 & $1,079,832$ \\
\hline Return on assets, EBIT (\%) & $\begin{array}{l}2.682 * * * \\
(0.062)\end{array}$ & 0.01 & $1,079,832$ \\
\hline Solidity (\%) & $\begin{array}{l}2.842 * * * \\
(0.118)\end{array}$ & 0.07 & $1,079,832$ \\
\hline Labor productivity (log) & $\begin{array}{l}-0.086 * * * \\
(0.003)\end{array}$ & 0.05 & $1,079,832$ \\
\hline Physical capital intensity (log) & $\begin{array}{l}0.251 * * * \\
(0.008)\end{array}$ & 0.12 & $1,079,832$ \\
\hline Skill intensity & $\begin{array}{l}-4.928 * * * \\
(0.169)\end{array}$ & 0.29 & $1,166,579$ \\
\hline Being part of an MNE $(1,0)$ odds ratio & $\begin{array}{l}0.280 * * * \\
(0.007)\end{array}$ & 0.27 & $1,166,467$ \\
\hline Being part of an enterprise group $(1,0)$ odds ratio & $\begin{array}{l}0.405 * * * \\
(0.006)\end{array}$ & 0.17 & $1,166,579$ \\
\hline Being an exporter $(1,0)$ odds ratio & $\begin{array}{l}0.801 * * * \\
(0.011)\end{array}$ & 0.16 & $1,166,579$ \\
\hline
\end{tabular}

Coefficients for all limited liability firms are from three pooled robust OLS, eight quantile, and two probit regressions of the dependent variable on the family firm dummy $(1,0)$ and firm size (except in the first and second regression), two- and three-digit industry dummies $(1,0)$, and year dummies $(1,0)$. All continuous variables are in logarithmic form except for Age and Skill intensity. Being part of an MNE, Being part of an enterprise group, and Being an exporter are expressed as odds ratios. Robust and clustered standard errors are shown in parenthesis. For brevity, other coefficient estimates are omitted. Full regression tables can be provided upon request. * $p<0.10$, ** $p<0.05$, *** $p<0.01$

using an equivalent probit specification in which the coefficients are presented as odds ratios, as follows:

Odds ratio $=\frac{\operatorname{Pr}(\text { Firm characteristic }=1 \mid \text { Family }=1)}{\operatorname{Pr}(\text { Firm characteristic }=1 \mid \text { Family }=0)}$

A majority of the continuous variables (EBIT, EBITDA, Labor productivity, Solidity, Physical capital intensity, Sales, and Total assets) were found to be skewed and to have non-normally distributed standard errors, indicating that they do not fulfill the conditions of an OLS estimator. Therefore, we analyze the abovementioned variables using a quantile regression model, which is estimated at the median. In this specification, industry is controlled for at the two-digit level
(NACE rev 1.1). For brevity, only the coefficients and standard errors regarding family ownership are included in Tables 7 and 8.

The results of Table 7 are similar to those of Table 6 in that family firms are found to have lesser employment, sales, and total assets than private non-family firms. Moreover, we find that the average family firm is approximately 2 years older than the average non-family firm. Family firms employ less human capital and are less likely to participate in multinational enterprises, enterprise groups, and exports. Moreover, they are again more profitable in terms of both EBIT and EBITDA, which implies that family control yields a positive payoff with respect to firm profitability. Furthermore, family firms have higher 
solidity. This may indicate a greater preference for control as well as risk aversion. Finally, family firms have lower labor productivity and higher physical capital intensity than private non-family firms. For labor productivity, this result is not surprising. Theory suggests that there is likely to be a tradeoff between concentration of ownership and productivity; that is, family firms are expected to be less productive than firms with dispersed ownership (e.g., Anderson and Reeb, 2003; Burkart 1997).

However, in terms of capital intensity, our results contradict previous research; family firms are often considered to have a lower capital intensity than other firms (Harris et a1994; Ward 1997; Hamelin 2013), whereas we find the opposite relationship. This result is puzzling and could be worthy of further analysis.

Next, we analyze the characteristics of family firms and private non-family firms by size class (Table 8).

Table 8 shows that the differences between family firms and private non-family firms are most pronounced among micro-sized firms (0-9 employees) and small firms (10-49 employees), while differences between medium-sized firms (50-249 employees) and large firms ( $\geq 250$ employees) are smaller. Once again, family firms have lesser amounts of total assets, employment, and sales across all size classes. They also have lower labor productivity, lower skill intensity, greater profitability, and are older than non-family firms. Among micro- and medium-sized firms, family firms have higher solidity than private non-family firms. Most family firms are less likely than private non-family firms to be part of a multinational enterprise or an enterprise group or to export; the only exception is large family firms, for which we find no differences in MNE participation and participation in enterprise groups.

Summarizing the results presented in this section, a prominent trait of family firms is that they are smaller than private non-family firms. Another prominent trait is that most family firms have higher solidity. Notably, in contrast to previous literature, we also find them to be more profitable. Additionally, they are less involved in exports, which is consistent with Westhead and Howorth (2006) and Fernandez and Nieto (2005; 2006). Finally, family firms are shown to rely less on formal education, perhaps suggesting that informal knowledge plays a greater role in family firms. The differences between family and private non-family firms are most significant among micro- and small-sized firms, and many firm characteristics converge with greater firm size, a result that is consistent with Habbershon (2006).
We reiterate that we interpret these econometric results as qualified correlations rather than causal relationships. We treat them as an initial description of the population of domestic family firms that may guide later research. The results suggest, for example, that family firms refrain from hiring as many employees as their non-family equivalents, a result that may be misleading from a policy perspective because the sheer number of employees does not necessarily reflect the full dynamics of employment. Bjuggren (2015) finds, for example, that employment within family firms is less sensitive to short-term shocks, suggesting that family firms have a longer planning horizon in their employment decisions.

\section{Concluding discussion}

This paper suggests that family firms are a prevalent and significant business model: they employ one third of the Swedish working population and generate an equivalent share of Swedish GDP. Our results demonstrate the need for knowledge and consideration of family firm dynamics among researchers and policy makers when designing measures aimed towards employment and economic growth. Although the economic significance of family firms has long been hypothesized, research has been limited by the inability to identify large parts of the population of family firms. Most previous research on family businesses has been restricted in its range, for example only investigating listed limited liability firms or using case studies. A large part of the family firm population has therefore been excluded from previous analyses. An exception that is closely related to our study is the work of Bjuggren et al. (2011), who used total population data to identify family firms in Sweden. Our results are consistent with theirs, although we found that family firms contributed a greater share of employment and GDP. This discrepancy likely arises because Bjuggren et al. (2011) were unable to study kinship for the entire population and therefore included a smaller range of family firms.

We contribute to the current literature by solving several methodological issues associated with identifying family firms and by establishing the first description of domiciled family firms across an entire economy. Our method has considerably greater range and precision than previous ones, as we use administrative data in conjunction with information on kinship, firm ownership, and firm governance to identify family firms 
Table 8 Comparison of the characteristics of limited liability family firms and private limited liability non-family firms (pooled OLS/ median/probit estimates) across size class (number of employed individuals) from 2004 to 2010

\begin{tabular}{|c|c|c|c|c|}
\hline \multirow{2}{*}{$\begin{array}{l}\text { Firm size } \\
\text { Dependent variable }\end{array}$} & Micro (0-9) & Small (10-49) & Medium (50-249) & Large $(\geq 250)$ \\
\hline & \multicolumn{4}{|c|}{ Explanatory variable, family firm dummy } \\
\hline \multirow[t]{2}{*}{ Age } & $2.364 * * *$ & $1.931 * * *$ & $2.008 * * *$ & 1.273 \\
\hline & $(0.073)$ & $(0.120)$ & $(0.287)$ & $(0.800)$ \\
\hline \multirow[t]{2}{*}{ Employment (log) } & $-0.491 * * *$ & $-0.123 * * *$ & $-0.090 * * *$ & $-0.182 * * *$ \\
\hline & $(0.005)$ & $(0.005)$ & $(0.011)$ & $(0.051)$ \\
\hline \multirow[t]{2}{*}{ Sales $(\log )$} & $-0.555^{* * *}$ & $-0.226 * * *$ & $-0.240 * * *$ & -0.133 \\
\hline & $(0.018)$ & $(0.022)$ & $(0.034)$ & $(0.083)$ \\
\hline \multirow[t]{2}{*}{ Total assets $(\log )$} & $-0.732 * * *$ & $-0.379 * * *$ & $-0.319 * * *$ & $-0.223 * * *$ \\
\hline & $(0.011)$ & $(0.013)$ & $(0.025)$ & $(0.069)$ \\
\hline \multirow[t]{2}{*}{ Return on assets, EBIT (\%) } & $4.723 * * *$ & $1.379 * * *$ & $1.337 * * *$ & $2.65 * * *$ \\
\hline & $(0.089)$ & $(0.167)$ & $(0.232)$ & $(0.851)$ \\
\hline \multirow[t]{2}{*}{ Return on assets, EBITDA (\%) } & $3.543 * * *$ & $1.005 * * *$ & $1.055 * * *$ & $2.223 * * *$ \\
\hline & $(0.080)$ & $(0.154)$ & $(0.229)$ & $(0.821)$ \\
\hline \multirow[t]{2}{*}{ Solidity (\%) } & $4.130 * * *$ & -0.152 & $1.127 * * *$ & 1.131 \\
\hline & $(0.156)$ & $(0.276)$ & $(0.391)$ & $(1.129)$ \\
\hline \multirow[t]{2}{*}{ Labor productivity (log) } & $-0.066 * * *$ & $-0.103 * * *$ & $-0.069 * * *$ & -0.025 \\
\hline & $(0.003)$ & $(0.004)$ & $(0.007)$ & $(0.021)$ \\
\hline \multirow[t]{2}{*}{ Physical capital intensity (log) } & $0.346 * * *$ & $0.078 * * *$ & $-0.088 * * *$ & $0.063 * * *$ \\
\hline & $(0.010)$ & $(0.019)$ & $(0.025)$ & $(0.085)$ \\
\hline \multirow[t]{2}{*}{ Skill intensity } & $-5.092 * * *$ & $-4.974 * * *$ & $-3.778 * * *$ & $-2.138 * * *$ \\
\hline & $(0.238)$ & $(0.204)$ & $(0.171)$ & $(0.806)$ \\
\hline \multirow[t]{2}{*}{ Being part of an MNE $(1,0)$ odds ratio } & $0.158 * * *$ & $0.398 * * *$ & $0.517 * * *$ & $0.457 * * *$ \\
\hline & $(0.005)$ & $(0.015)$ & $(0.033)$ & $(0.074)$ \\
\hline \multirow[t]{2}{*}{ Being part of an enterprise group $(1,0)$ odds ratio } & $0.325 * * *$ & $0.567 * * *$ & $0.599 * * *$ & 0.811 \\
\hline & $(0.006)$ & $(0.014)$ & $(0.042)$ & $(0.190)$ \\
\hline \multirow[t]{2}{*}{ Being an exporter $(1,0)$ odds ratio } & $0.814 * * *$ & $0.724 * * *$ & $0.606 * * *$ & 0.759 \\
\hline & $(0.014)$ & $(0.019)$ & $(0.039)$ & $(0.134)$ \\
\hline Observations $^{\Psi}$ & 882,143 & 60,605 & 22,583 & 1951 \\
\hline
\end{tabular}

Coefficients for all limited liability firms are from three pooled OLS, seven quantile, and two probit regressions of the dependent variable on the family firm dummy $(1,0)$ and firm size (except in the first and second regression), two- and three-digit industry dummies $(1,0)$, and year dummies (1,0). All continuous variables are in logarithmic form except for Age and Skill intensity. Being part of an MNE, Being part of an enterprise group, and Being an exporter are expressed as odds ratios. Robust and clustered standard errors are shown in parenthesis. For brevity, other coefficient estimates and statistics are omitted. Full regression tables can be provided upon request

$* p<0.10, * * p<0.05, * * * p<0.01$

${ }^{\Psi}$ The number of observations differs slightly across regressions. Therefore, we present the minimum number of observations included in each firm size category

across the entire Swedish firm population. Our approach can capture the dynamics between families and firms across all domiciled limited liability firms, partnerships and sole proprietorships, which includes all legal forms of family firms. The method presented is generally applicable to any administrative dataset containing similar information; therefore, we hope that our results may guide future family business research both in Sweden and internationally. Moreover, our method allows comparison between different time periods; that is, the same method can be used to identify family firms in later years. This will render it possible to use register data to conduct long-term longitudinal studies across all domiciled family firms in the future.

By applying our method, we find that family firms are less reliant on formal knowledge. This could be due 
to spatial factors; for instance, family firms are more likely to survive and grow in sparse economic environments with low general levels of education. Alternatively, it could indicate that family firms have a higher dependence on tacit knowledge to develop and maintain their businesses. The characteristics of family and private non-family firms are generally found to converge with greater firm size, apart from firm size and profitability. Consistent with previous literature, we find that family firms on average have lesser amounts of total assets, employment, and sales than private non-family firms, even within the same size class. We also find that family firms have higher solidity and are more profitable. Moreover, we show that the term "family firm" includes a wide variety of entities from small firms to large traded companies. Family firms are active in all industries except when crowded out by government actors. Given Sweden's large public sector, it is likely that family firms contribute even more in other countries.

Finally, our results show that limited liability firms are the most economically interesting group among family firms because the bulk of economic activity occurs within them. Sole proprietorships and partnerships are still of significant interest, however, as they may exhibit unique family firm characteristics that set them apart from family controlled limited liability firms. We find that sole proprietorships constitute a majority of all family firms and that they employ a noteworthy share of the working population.

In conclusion, our results emphasize the need for nuance in the discussion of family firms, an area in which the traditional rhetoric has been characterized by considering family firms as a homogenous group of small firms with no growth ambitions and low profitability. By contrast, our results suggest that family firms have similar growth potential to that of non-family firms. This is relevant for economic policy targeting growth because family firms are likely to require different types of growth policies than non-family firms. For example, it is generally thought that family firms value independence and control and are more risk averse than non-family firms. This perception derives from the fact that family firms are less willing to finance profitable investments with external capital compared to other firms, and they are more apprehensive to hire new employees. Therefore, policymakers may find that family firms respond better to strategies such as increased opportunities for organic growth and flexibility in employment contracts rather than increased access to external capital, which has been a common policy strategy in recent years. Our results suggest that policymakers and economists should consider the specific characteristics of family firm ownership, which could significantly improve the efficiency and accuracy of economic policy across a large number of firms. Moreover, we find that there are significant differences among family firms. This suggests that researchers and policymakers must consider not only whether a firm is family controlled but also its size, industry, and legal form. This may also explain why previous researchers have reached seemingly contradictory conclusions regarding the characteristics of family firms.

One limitation to our study is that we cannot distinguish foreign-controlled family firms from foreigncontrolled non-family firms. Thus, our analysis excluded some of the largest family-owned firms in Sweden such as IKEA. Omitting these firms means that we may have missed important dynamics of family ownership. Another limitation is that our study is descriptive and did not attempt to discern causal relationships with which to guide future research. This was a deliberate choice because a causal analysis was outside the scope of this paper.

For future research, we suggest two ways in which our method can be improved: First, it would be desirable to develop a method to identify kinship structures across countries, which would make it possible to identify foreign-controlled family firms. Because our study considers only domiciled family firms, our results can be considered a lower bound in terms of the economic contribution of family firms; these results exclude firms owned by foreigners and Swedish family firms owned from abroad. Second, it would be helpful to further differentiate among family firms and specifically to identify entrepreneurial family firms that are innovative, have growth ambitions, and are driven by profit motives. This approach could increase our understanding of family firm growth and consequently the driving forces of the overall economy.

Acknowledgements Lodefalk gratefully acknowledges financial support from the Jan Wallander and Tom Hedelius Research Foundation. Karlsson gratefully acknowledges financial support from the Swedish Agency for Economic and Regional Growth. We are grateful for comments from Anders Bornhäll, Agelos Delis, and Niklas Rudholm and participants of seminars at the Centre for Family Enterprise and Ownership (CeFEO), the 2016 HUI Research workshop, the 2016 Swedish Graduate Program in Economics (SWEGPEC) workshop, and the 16th International Schumpeter Society Conference, Aston University and at Örebro University. 


\section{Appendix}

Table 9 Data registers used and their Swedish translations

\begin{tabular}{|c|c|}
\hline The Swedish Business Register & Företagsdatabasen \\
\hline The Swedish Population Register & Registret över totalbefolkningen \\
\hline The Swedish Register-Based Labor Market Statistics & Registerbaserad arbetsmarknadsstatistik \\
\hline The Swedish Ownership Register & Ägarregistret \\
\hline $\begin{array}{l}\text { The Swedish Financial Supervisory Authority's Central Register of Investments and Investor } \\
\text { Alerts }\end{array}$ & $\begin{array}{l}\text { Finansinspektionens insynsregister och } \\
\text { börsinformation }\end{array}$ \\
\hline The Swedish Companies Registrations Office's Executive Board Register & Styrelseregistret \\
\hline The Swedish Tax Agency's statistics of earnings and deductions & Skatteregistret \\
\hline The Swedish Structural Business Statistics & Företagens ekonomi \\
\hline The Swedish Multi-generation Register & Flergenerationsregistret \\
\hline
\end{tabular}

Open Access This article is distributed under the terms of the Creative Commons Attribution 4.0 International License (http:// creativecommons.org/licenses/by/4.0/), which permits unrestricted use, distribution, and reproduction in any medium, provided you give appropriate credit to the original author(s) and the source, provide a link to the Creative Commons license, and indicate if changes were made.

\section{References}

Anderson, R. C., \& Reeb, D. M. (2003). Founding-family ownership and firm performance: evidence from the S\&P 500. The Journal of Finance, 58(3), 1301-1328. doi:10.1111/15406261.00567.

Andersson, W. F., Johansson, D., Karlsson, J., Lodefalk, M., \& Poldahl, A. (2017). The characteristics and performance of family firms: exploiting information on ownership, kinship and governance using total population data. Örebro: Örebro University.

Astrachan, J., \& Shanker, M. (1996). Myths and Realities: Family Businesses' Contribution to the US Economy - A Framework for Assessing Family Business Statistics. Family Business Review, 9(2), 107-123. https://doi.org/10.1111/j.17416248.1996.00107.x.

Astrachan, J. H., \& Shanker, M. C. (2003). Family businesses' contribution to the U.S. economy: a closer look. Family Business Review, 16(3), 211-219. doi:10.1111/j.17416248.2003.tb00015.x.

Backman, M., \& Palmberg, J. (2015). Contextualizing small family firms: how does the urban-rural context affect firm employment growth? Journal of Family Business Strategy, 6, 247-258. doi:10.1016/j.jfbs.2015.10.003.

Benavides-Velasco, C. A., Quintana-García, C., \& Guzmán-Parra, V. F. (2013). Trends in family business research. Small
Business Economics, 40(1), 41-57. doi:10.1007/s11187011-9362-3.

Bennedsen, M., Nielsen, K. M., Pérez-González, F., \& Wolfenzon, D. (2007). Inside the family firm: the role of families in succession decisions and performance. The Quarterly Journal of Economics, 122(2), 647-691. doi:10.1162 /qjec.122.2.647.

Bertrand, M., \& Schoar, A. (2006). The role of family in family firms. Journal of Economic Perspectives, 20(2), 73-96. doi:10.1257/jep.20.2.73.

Birch, D. (1979). The job generation process. final report to Economic Development Administration. Cambridge: MIT Program on Neighborhood and Regional Change.

Birch, D. L., \& Medoff, J. (1994). Gazelles. In L. C. Solmon \& A. R. Levenson (Eds.), Labor markets, employment policy and job creation (pp. 159-167). Boulder and London: Westview Press.

Bird, B., Welsch, H., Astrachan, J. H., \& Pistrui, D. (2002). Family business research: the evolution of an academic field. Family Business Review, 15, 337-350. doi:10.1111/j.17416248.2002.00337.x.

Bjuggren, Carl Magnus. (2013). "Family matters essays on family firms and employment protection", Ph.D.-thesis in Economics, Linköping Studies in Arts and Science No. 592, Linköping University.

Bjuggren, C. M. (2015). Sensitivity to shocks and implicit employment protection in family firms. Journal of Economic Behavior and Organization, 119, 18-31. doi:10.1016/j. jebo.2015.07.011.

Bjuggren, C. M., Daunfeldt, S.-O., \& Johansson, D. (2013). Highgrowth firms and family ownership. Journal of Small Business and Entrepreneurship, 26(4), 365-385. doi:10.1080/08276331.2013.821765.

Bjuggren, C. M., Johansson, D., \& Sjögren, H. (2011). A note on Swedish family-owned businesses, employment, and GDP: a descriptive analysis. Family Business Review, 24(4), 362371. doi: $10.1177 / 0894486511420138$. 
Bornhäll, A., Johansson, D., \& Palmberg, J. (2016). The capital constraint paradox in micro and small family and nonfamily firms. Journal of Entrepreneurship and Public Policy, 5(1), 38-62. doi:10.1108/JEPP-10-2015-0033.

Burkart, M., Gromb, D., \& Panunzi, F. (1997). Large shareholders, monitoring, and the value of the firm. Quarterly Journal of Economics, 112, 693-728. doi:10.1162/003355397555325.

Casillas, J., \& Acedo, F. (2007). Evolution of the intellectual structure of family business literature: a bibliometric study of FBR. Family Business Review, 20(2), 141-162. doi:10.1111/j.1741-6248.2007.00092.x.

Chandler, A. (1990). Scale and scope: the dynamics of industrial capitalism. Cambridge: Harvard University Press, Belknap Press.

Davis, J. A., \& Tagiuri, R. (1996). Bivalent attributes of the family firm. Family Business Review, 9(2), 199-208. doi:10.1111 /j.1741-6248.1996.00199.x.

Colli, A. (2003). The History of Family Business (pp. 1850-2000). Cambridge University Press: Cambridge.

Demsetz, H., \& Lehn, K. (1985). The structure of corporate ownership: causes and consequences. Journal of Political Economy, 93(6), 1155-1177. doi:10.1086/261354.

Donckels, R., \& Frohlich, E. (1991). Are family businesses really different? European experiences from STRATOS. Family Business Review, 4(2), 149-160. doi:10.1111/j.17416248.1991.00149.x.

Dow, S., \& McGuire, J. (2016). Family matters?: A cross-national analysis of the performance implications of family ownership. Corporate Governance: An International Review, 24(6), 584-598. doi:10.1111/corg.12155.

Dyer, W. G., Jr. (2006). Examining the 'Family Effect' on Firm Performance. Family Business Review, 19(4), 253-273. doi:10.1111/j.1741-6248.2006.00074.x.

European Commission. (1994). Commission recommendation of 7 December 1994 on the transfer of small and medium-sized enterprises. http://eurlex.europa.eu/LexUriServ/LexUriServ. do?uri=CELEX:31994H1069:en:HTML.380. Downloaded by [158.105.19.37] at 05:22 19 August 2013 .

European Commission. (2006). Commission communication from 14 March 2006: Transfer of businesses - continuity through a new beginning. http://eur-lex.europa.eu/LexUriServ/ LexUriServ.do?uri=COM:2006:0117:FIN:EN:PDF.

European Commission. (2009). Final report of the expert group. Overview of family-business-relevant issues: research, networks, policy measures and existing studies. http://ec.europa. eu/enterprise/policies/sme/

Evert, R., Martin, J., McLeod, M., \& Payne, G. (2016). Empirics in family business research: progress, challenges, and the path ahead. Family Business Review, 29(1), 17-43. doi:10.1177/0894486515593869.

Faccio, M., \& Lang, L. (2002). The ultimate ownership of Western European corporations. Journal of Financial Economics, 65(3), 365-395. doi:10.1016/S0304-405X(02)00146-0.

Fernàndez, Z., \& Nieto, M. (2005). Internationalization strategy of small and medium-sized family businesses: some influential factors. Family Business Review, 18(1), 77-89. doi:10.1111 j.1741-6248.2005.00031.x.

Fernàndez, Z., \& Nieto, M. (2006). Impact of ownership on the international involvement of SMEs. Journal of International Business Studies, 37, 340-351. doi:10.1057/palgrave. jibs.8400196.
Garcia-Castro, R., \& Aguilera, R. V. (2014). Family involvement in business and financial performance: a set-theoretic crossnational inquiry. Journal of Family Business Strategy, 5(1), 85-96. doi:10.1016/j.jfbs.2014.01.006.

Gedajlovic, E., Carney, M., Chrisman, J. J., \& Kellermanns, F. W. (2012). The adolescence of family firm research: taking stock and planning for the future. Journal of Management, 38(4), 1010-1037. doi:10.1177/0149206311429990.

Grundström, C., Öberg, C., \& Rönnbäck, A. (2012). Familyowned manufacturing SMEs and innovativeness: a comparison between within-family successions and external takeovers. Journal of Family Business Strategy, 3(3), 162-173. doi:10.1016/j.jfbs.2012.07.001.

Habbershon, T. (2006). Commentary: a framework for managing the familiness and agency advantages in family firms. Entrepreneurship: Theory and Practice, 30(6), 879-886. doi:10.1111/j.1540-6520.2006.00158.x.

Hamelin, A. (2013). Influence of family ownership on small business growth. Evidence from French SMEs. Small Business Economics, 41, 563-579. doi:10.1007/s11187012-9452-x.

Handler, W. C. (1989). Methodological issues and considerations in studying family businesses. Family Business Review, 2(3), 257-276. doi:10.1111/j.1741-6248.1989.00257.x.

Harris, D., Martinez, J., \& Ward, J. (1994). Is strategy different for the family-owned business? Family Business Review, 7(2), 159-174. doi:10.1111/j.1741-6248.1994.00159.x.

Henrekson, M. (2005). Entrepreneurship: a weak link in the welfare state? Industrial and Corporate Change, 14(3), 437467. doi:10.1093/icc/dth060.

Henrekson, M. (2017). Taxation of Swedish firm owners: the great reversal from the 1970s to the 2010s. Nordic Tax Journal, forthcoming.

Henrekson, M., \& Johansson, D. (1999). Institutional effects on the evolution of the size distribution of firms. Small Business Economics, 12(1), 11-23. doi:10.1023/A:1008002330051.

Henrekson, M., \& Johansson, D. (2009). Competencies and institutions fostering high-growth firms. Foundations and Trends in Entrepreneurship, 5(1), 1-80. doi:10.1561/0300000026.

Henrekson, M., \& Sanandaji, T. (2014). Small business activity does not measure entrepreneurship. Proceedings of the National Academy of Sciences of the United States of America (PNAS), Early Edition, January 21, 2014, DOI: 10.1073/pnas.1307204111.

Henrekson, M., \& Stenkula, M. (Eds.). (2015). Swedish taxation: development since 1862. New York: Palgrave Macmillan.

Hiebl, M. R. W. (2012). Risk aversion in family firms: what do we really know? The Journal of Risk Finance, 14(1), 49-70. doi:10.1108/15265941311288103.

Hiebl, M. R. W. (2014). Risk aversion in the family business: the dark side of caution. Journal of Business Strategy, 35(5), 3842. doi:10.1108/JBS-09-2013-0087.

Himmelberg, C., Hubbard, R., \& Palia, D. (1999). Understanding the determinants of managerial ownership and the link between ownership and performance. Journal of Financial Economics, 53, 353-384. doi:10.1016/S0304-405X(99 )00025-2.

Holmén, M., \& Högfeldt, P. (2009). Pyramidal discounts: tunneling or overinvestment? International Review of Finance, 9(1-2), 133-175. doi:10.1111/j.1468-2443.2009.01088.x. 
Johansson, D., Stenkula, M., \& Du Rietz, G. (2016). Capital income taxation of Swedish households, 1862-2010. Scandinavian Economic History Review, 63(2), 154-177. doi:10.1080/03585522.2014.980314.

Kontinen, T., \& Ojala, A. (2010). The internationalization of family business: a review of extant research. Journal of Family Business Strategy, 1(2), 97-107. doi:10.1016/j. jfbs.2010.04.001.

Kraus, S., Harms, R., \& Fink, M. (2011). Family firm research: sketching a research field. International Journal of Entrepreneurship and Innovation Management, 13(1), 3247. doi:10.1504/IJEIM.2011.038446.

La Porta, R., Lopez-de-Silanes, F., \& Shleifer, A. (1999). Corporate ownership around the world. The Journal of Finance, 54(2), 471-517. doi:10.1111/0022-1082.00115.

Landes, D. (1949). French entrepreneurship and industrial growth in the nineteenth century. Journal of Economic History, 9(1), 45-61. doi:10.1017/S002205070009032X.

Mazzi, C. (2011). Family business and financial performance: current state of knowledge and future research challenges. Journal of Family Business Strategy, 2(3), 166-181. doi:10.1016/j.jfbs.2011.07.001.

Mandl, I. (2008). Overview of family business relevant issues, final report. Vienna: Austrian Institute for SME Research $<\mathrm{http}: / / \mathrm{ec}$. europa.eu/enterprise/entrepreneurship/craft/family_ business/family_business_en.htm>.

Miller, D., \& Le Breton-Miller, I. (2015). The arts and family business: linking family business resources and performance to industry characteristics. Entrepreneurship: Theory and Practice, 39(6), 1349-1370. doi:10.1111/etap.12177.

Morck, R., Wolfenzon, D., \& Yeung, B. (2005). Corporate governance, economic entrenchment, and growth. Journal of Economic Literature, 43(3), 655-720. doi:10.1257 /002205105774431252.

Penrose, E. T. (1959). The theory of the growth of the firm. Oxford: University Press, fourth edition.

Poutziouris, P., Smyrnios, K., \& Klein, S. (2006). Handbook of research on family business. Cheltenham: Edward Elgar.

SFS (Swedish Code of Statutes) No. (1999). 1229. Inkomstskattelag [Income Tax Law]. Stockholm, Sweden: Finansdepartementet.
Shanker, M. C., \& Astrachan, J. H. (1996). Myths and realities: family businesses' contribution to the US economy-a framework for assessing family business statistics. Family Business Review, 9, 107-123. doi:10.1111/j.17416248.1996.00107.x.

Sharma, P., Chrisman, J., \& Chua, J. (1997). Strategic management of the family business: past research and future challenges. Family Business Review, 10(1), 1-35. doi:10.1111 /j.1741-6248.1997.00001.x.

Sharma, P. (2004). An overview of the field of family business studies: current status and directions for the future. Family Business Review, 17(1), 1-36. doi:10.1111/j.17416248.2004.00001.x.

Sirmon, D., \& Hitt, M. (2003). Managing resources: linking unique resources, management, and wealth creation in family firms. Entrepreneurship Theory and Practice, 27(4), 339358. doi:10.1111/1540-8520.t01-1-00013.

Statistics Sweden. (2014). Public finances in Sweden 2014. Örebro: Sweden.

Sundqvist, S-I. 1985-2009. Owners and power in Sweden's listed companies. Stockholm: SIS Ägarservice AB (1994-2002 with A. Sundin, and 2003-2006 with D. Fristedt).

Swedish Tax Authority. (2015). Skatteregler för delägare $i$ fämansbolag [Taxation rules for partners in closely held firms]. Sweden: Stockholm.

Ward, J. L. (1997). Growing the family business: special challenges and best practices. Family Business Review, 10(4), 323-337. doi:10.1111/j.1741-6248.1997.00323.x.

Westhead, P., \& Howorth, C. (2006). Ownership and management issues associated with family firm performance and company objectives. Family Business Review, 19(4), 301-316. doi:10.1111/j.1741-6248.2006.00077.x.

Xi, J., Kraus, S., Filser, M., \& Kellermanns, F. (2015). Mapping the field of family business research: past trends and future directions. International Entrepreneurship and Management Journal, 11, 113-132. doi:10.1007/s11365-013-0286-z.

Yu, A., Lumpkin, G. T., Brigham, K. H., \& Sorenson, R. L. (2012). The landscape of family business outcomes: a summary and numerical taxonomy of dependent variables. Family Business Review, 25(1), 33-57. doi:10.1177 /0894486511430329. 